\title{
THE ANALYSIS WITH STRUCTURAL EQUATION MODELLING OF THE FACTORS THAT DETERMINE CITIZENS' SATISFACTION WITH SOCIAL SERVICES AND AIDS PROVIDED BY LOCAL GOVERNMENTS
}

\author{
Gonca GÜNGÖR GÖKSU ${ }^{1}$
}

\begin{abstract}
The aim of the study is to analyze the factors which are affecting the satisfaction of citizens from social services and aids provided by local governments through structural equation modeling. Another aim that is wanted to reach in the study is to be determined elements which should be considered in being prepared a local government budget sensitive to social needs. In the context of the study, a scale which name is "Citizens' Satisfaction from Social Services and Social Assistance Provided by Local Authorities" has been improved. Primarily, a survey form which consists of 40 questions related to social services and aids that are in the duties and responsibilities of local governments was prepared. In order to determine the satisfaction levels of 800 voluntary participants who live in Sakarya city from social services and aids performed by local administrations, their ideas were asked to declare. The statements in the survey were designed by considering various laws and reviewing literature. In the first step of analyzing, percentages of responses to related expressions were calculated so that according to $2 / 3$ relative unanimity rule, every statement which was replied as total $66.6 \%$ positively were included in explanatory factor analysis. In the next step, the main factors obtained through the explanatory factor analysis were undergone both a first-degree and second-degree confirmatory factor analysis. When evaluated the results of the study, it was concluded that total twenty-nine statements, which affects the satisfaction levels of citizens from social services and social assistance provided by local authorities, loaded under five main factors. Moreover, the finding was reached that one unit increases in these five main factors have effects changing between 0.67 and 0.92 on the satisfaction levels of citizens.
\end{abstract}

Keywords: Local Government, Social Work, Social Assistance, Structural Equation Modelling

JEL Code: H55, H72, H75

\section{Introduction}

Following the 1929 Great Depression, social or welfare state, which had come into play along with the implementation of Keynesian economic policies (Gül, 2013: 69), began losing influence in many countries including the United States of America by the second half of 1970s. When Neo-liberal economic policies took over, after 1980 in specific, social services offered by local governments as well as the central administration were severely criticized, resulting in various restrictions due to the fact that social spending was reduced by Neo-liberal economic policies in numerous countries. Subsequently, practices based on global competition and minimization of state had a deep impact on actions for social policies (Güloğlu and Es, 2008: 259). Fast forward to today, not only central administration, but also local governments are considered a means for developing solutions for social issues, since the rise in capital stock, global advances in information and communication technologies and central administration placing emphasis on

1 Dr., Sakarya University, Public Finance Department, ggungor@sakarya.edu.tr 
regulatory and supervisory policies by the late 20th century made for higher significance in local governments. (Caner and Açıkalın, 2008: 274). Meanwhile, local governments are entities of public service closest to the local people that carry out social policies and services responsibly (Aydın, 2008: 17).

Both municipalities and provincial special administrations were charged with vital duties within the scope of social policies in Turkey. The Metropolitan Municipal Law (no: 5216), The Municipal Law (no: 5393), The Law on Aiding the Military Families in Need (no: 4109), The Municipal Revenues Law (no: 2464), The Law on Wages for Artists, Specialists, Servants and Interns with the Municipal Operas and Theaters (no: 37), The Environmental Law (no: 2872), The Law on the Preservation of Cultural and Natural Assets (no: 2863), The Law on Cinema, Video and Music Works (no: 3257 ) contain the relevant articles with respect to social municipality whereas the Law of Provincial Special Administration is comprised of the responsibilities undertaken by the provincial special administrations in terms of social services and aids. The primary focus of this study is, through structural equation modeling, to analyze the factors affecting the level of satisfaction of citizens pertaining to social services and aids provided by local governments. Secondarily, it is the designation of items to consider while preparing a local government budget that is liable for social needs.

\section{Conceptual Analysis of Social Services and Aids}

The concept of social policies, which fundamentally aims to meet the social needs and increase the welfare level of individuals, analyzes the connection between the practices of social services and welfare state and the community and politics. Additionally, another important framework is the examination of the impact of economic actions on the people as well as the social events they cause. (Tiyek, 2012: 55-56). It would be more accurate to distinguish the concept of social policies as narrow-scoped and far-reaching because they respectively involve conflicts between the employer and employees only in the capitalist system, and the social development, justice, balance, integration and the overall social development bringing solutions to social groups in all social domains. (Güloğlu and Es, 2008: 259).

This study was based on the wide use of the concept of social policies as its extended definition is: (1) To administer social services including fair income distribution, health, housing, education and social services policies, (2) To focus in on the needs and issues that have an effect on the receivers of the service including policies of the poor, old, disabled as well as families. (3) To provide higher prosperity. (Spicker, 2007). One prominent means of social policies is the social security, which is implemented in three ways: social insurance, social services and aids. Social insurance rests against premium while the latter involves non-premium based practices, financed by taxes. (Güloğlu and Es, 2008: 260). Social services and aids are influential in providing social involvement for disadvantaged individuals and groups in terms of ensuring social justice and the mission of being a social citizen. (Altuntaş, 2009: 170). Thus, the concept of social services is used to mean services provided publicly or in private in order to aid disadvantaged or defenseless individuals and groups (Pinker, 2018) whereas the concept of social aids is defined as any aid in kind or financial aid provided outright by public institutions and foundations for those in need. (Türkoğlu, 2013: 280). In a nutshell, social aids are outright financial aids and social services are a way of providing specific services. (Güloğlu and Es, 2008: 260). 


\section{The Scope of Social Services and Aids Provided by Local Governments}

Local governments that function as units of autonomous government are municipalities, provincial administration and borough administrations in Turkey (Tiyek, 2012: 54) and they are not directly dependent on the central government since local governments are authorized to regulate and administer the majority of public events responsibly, within the interest of local people. Therefore, the existence of free decision-making bodies allows local governments to possess administrative and financial autonomy (Küçük, 2018: 36). However, due to a lack of income and staff, provincial administrations were bound to perform actions exposed to the central government, which led to their gradual dysfunction. As a result, municipal administrations came to be the main foundations of local governments (Republic of Turkey, General Directorate of Families and Social Research, 2010:42).As previously explained in the introduction section, social services and aids that local governments in Turkey are in charge of are stated in a good many scopes of law. Nonetheless, it is unfeasible to elaborate on all the social services and aids provided by local governments in this study owing to the page limitation. Just the same, they can be grouped under three basic categories: (1) Providing cash money, clothes, food, fuel, scholarships for the elderly, disabled, poor, defenseless children, women, families and young people, (2) Services on health, education, housing, artistic and cultural events, (3) Services on the protection of the environment, natural assets and urban history.

\section{Research Analysis and Findings}

Within the scope of the study, a scale called "Satisfaction of Citizens from Social Services and Social Aids that is Provided by Local Governments", which consists of five dimensions and 30 questions, has been developed. This scale has been prepared to determine the public services that directly affect the satisfaction of citizens from social services and social aids which are provided by local administrations and to determine these services are loaded on which factors. All analyzes were performed using SPSS 22 and AMOS 20 package programs. Exploratory factor analysis was applied to the observed variables (questions) with SPSS 22 program. According to findings, a total of 30 observed variables were collected under five factors. In Table 1, factors and the reliability analysis results of each factor are included. When reliability analysis was implemented to all questions at the same time, the result achieved was 0.923 , and this value indicates that the scale has been reliable and valid.

Table 1. Rotated Factor Analysis and Reliability Analysis Results of Each Factor

\begin{tabular}{|c|l|l|c|}
\hline Factor & Factor Name & Question No & $\begin{array}{c}\text { Cronbach's } \\
\text { Alpha }\end{array}$ \\
\hline 1 & Priority Social Services and Aids & $1,2,3,4,5,6,7,8,9,10,11,12,13$ & .892 \\
\hline 2 & $\begin{array}{l}\text { Participatory Budgeting and Social } \\
\text { Goals }\end{array}$ & $14,15,16,17,18,19,20$ & .771 \\
\hline 3 & $\begin{array}{l}\text { Competency and Social } \\
\text { Development }\end{array}$ & $21,22,23$ & .642 \\
\hline 4 & $\begin{array}{l}\text { Transport Network and City } \\
\text { Protection }\end{array}$ & $24,25,26,27$ & .798 \\
\hline 5 & Other Social Services & $28,29,30$ & .549 \\
\hline
\end{tabular}

Source: Own elaboration from SPSS 22 outputs. 
Figure 1. The First Level Confirmatory Factor Analysis

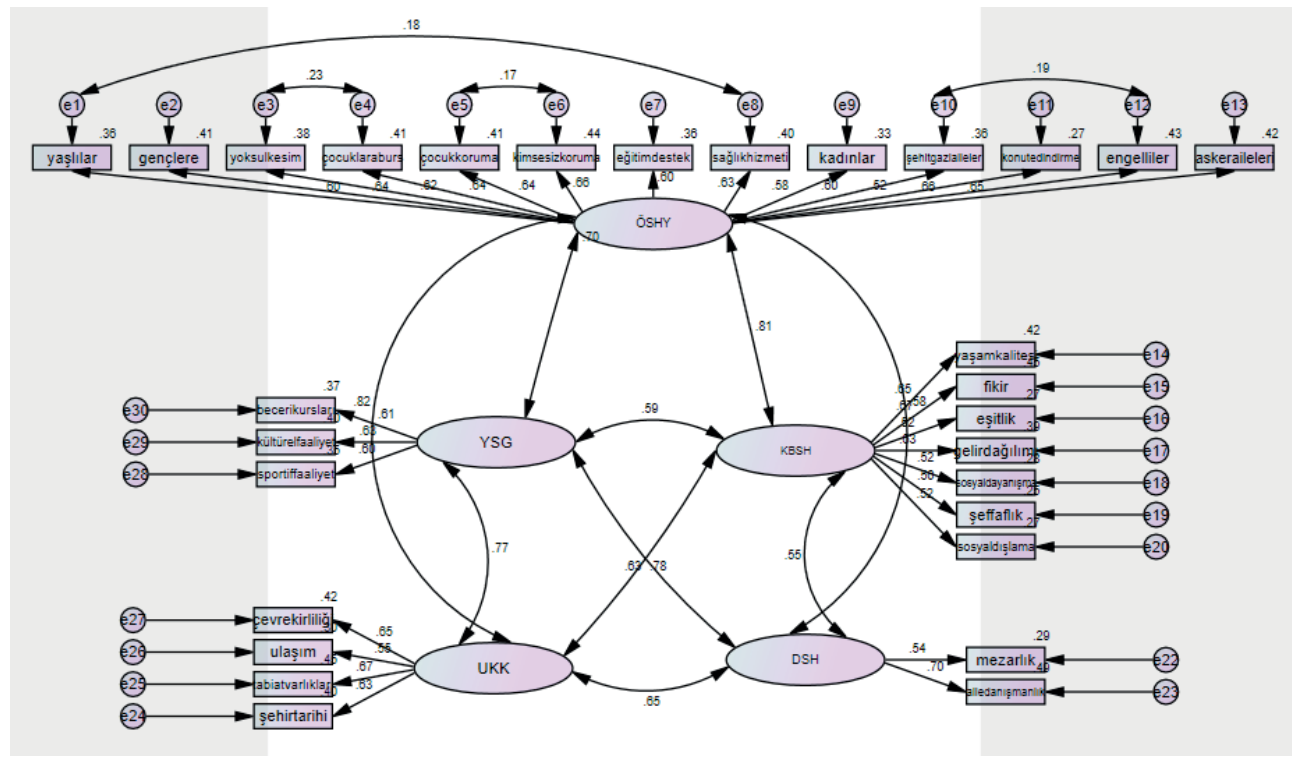

Source: Own elaboration from AMOS 20 outputs.

Five factors determined by explanatory factor analysis were re-analyzed using AMOS 20 program. Figure 1 shows the results obtained with the first level confirmatory factor analysis. According to the results of the analysis, the results of goodness of fit (CMIN/DF $=2.89, \mathrm{GFI}=.915, \mathrm{CFI}=.911$, $\mathrm{RMR}=0.045$ and RMESA $=0.049$ ) are in the desired range. However, the statement of "Local governments should give importance to religious services", which had a load of 0.264 , was left out of the analyze because its loading was inadequate to explain the size of Other Social Services. At the next step, a total of 29 observed variables were analyzed again. When the analysis was repeated with 29 observed variables, it has been concluded that the regression coefficients of all observed variables were found significant $(P=.000)$. More clearly; it has been seen that all of the observed variables are indicative of the factor at which they are loaded. Figure 1 shows the first level confirmatory factor analysis. The effects of observed variables on the latent variables are included in the figure. According to the standard regression weights obtained in the study:

i. The question that most influenced the factor of Priority Social Services and Aids is the statement "Local government should give importance to the services for homeless" with a load of 0.659.

ii. The question that most influenced the factor of Participatory Budget and Social Targets is the statement "Local governments should take the ideas of local people in order to determine social needs" with a load of 0.670 .

iii. The question that most influenced the factor of Competency and Social Development has been the statement "Local governments should pay attention to art and cultural activities" with a load of 0.629 .

iv. The question that most influenced the factor of Transportation Network and City Protection has been the statement "Local governments should give importance to services to protect natural assets" with a load of 0.670 .

v. The question that most influenced the factor of Other Social Services has been the statement "Local governments should give importance to family counseling services" with a load of 0.702 . 
Figure 2 shows the results of the second level confirmatory factor analysis. Goodness of fit (CMIN/ $\mathrm{DF}=3.04, \mathrm{GFI}=.913, \mathrm{CFI}=.907, \mathrm{RMR}=.046$ and $\mathrm{RMESA}=.051$ ) were found in the desired range and all regression coefficients were found significant $(P=.000)$. According to the results, while the factor of Transportation Network and City Protection that has a load of 0.92 affects mostly the satisfaction of citizens from the social services and aids provided by local governments, the least affecting factor with a load of 0.67 is the Other Social Services.

Figure 2. The Second Level Confirmatory Factor Analysis

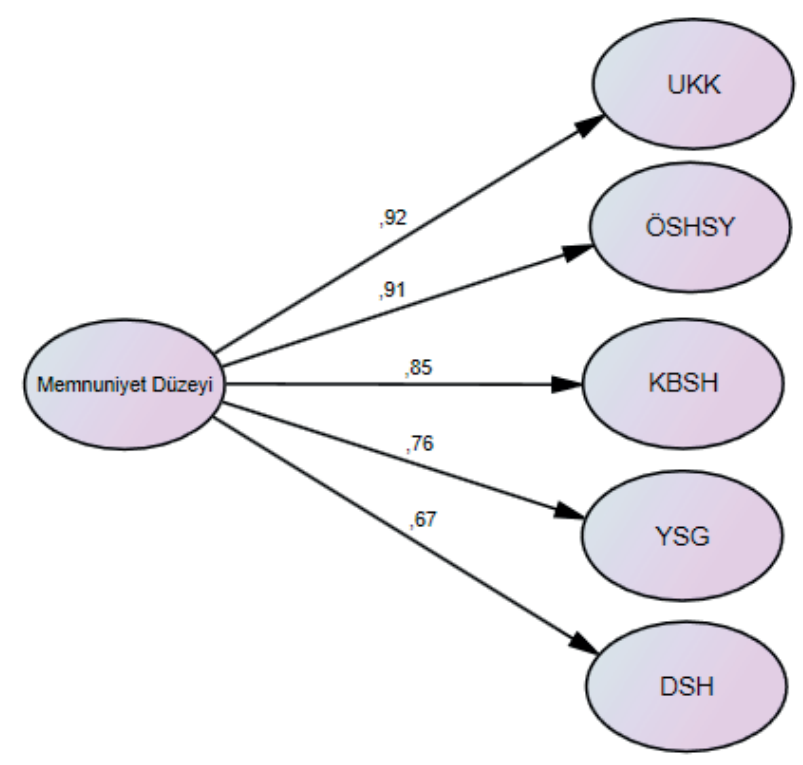

Source: Own elaboration from AMOS 20 outputs.

\section{Conclusion and Evaluation}

When the results of the study have been generally evaluated, the first conclusion was found that 1 unit increase in the services of the transportation network and city protection causes the increase of 0.92 on the satisfaction of citizens from the social services and aids provided by local governments. Among other findings were reached that (i) 1 unit increase in priority social services and social aids causes the increase of 0.91 on the satisfaction of citizens, (ii) 1 unit increase in services regarding participatory budget and social targets causes the increase of 0.85 on the satisfaction level, (iii) 1 unit increase in services regarding competency and social development causes the increase of 0.76 on satisfaction level, and (iv) 1 unit increase in other social services causes the increase of 0.67 on satisfaction level. It is thought that the study will contribute to the literature and inform local authorities about the subject. 


\section{References}

Altuntaş, B. (2009). "The evaluation of Social Services and Aids in Turkey within the Context of Social Rights and Social Justice", http://www.sosyalhaklar.net/2009/bildiri/altuntas.pdf, 13.12.2018.

Aydın, M. (2008). Social Policy and Local Governments, İstanbul, Yedirenk Publishing.

Caner, C. \& Açıkalın, N. (2008). "Structural Transformation of the Welfare State in Globalization Process in Turkey: Local Government Reform", 1. National Local Governments Symposium Proceedings Book, İstanbul, Erkam Publishing.

Güloğlu, T. \& Es, M. (2008). "Localized Social Aids and Social Services", 1. National Local Governments Symposium Proceedings Book, İstanbul, Erkam Publishing.

Küçük, H. (2018). "Control of Municipalities in Local Autonomy Context: The Case of Italy and Turkey", Marmara University, Journal of Political Science, 6(1), pp.35-60.

Pinker, R. A. (2018). Social Service, https://www.britannica.com/topic/social-service, 13.12.2018.

Spicker, P. (2018). An Introduction to Social Policy, http://spicker.uk/social-policy/, 13.12.2018.

T.R. General Directorate of Family and Social Research (2010). The Perception of Social Aids and Poverty Culture: The Research of Aid Perceptions of People Who Receive Public Social Aid and Poverty Culture in Turkey, Ankara, General Publication No: 144.

Tiyek, R. (2012). "The Role of Local Governments in Social Policy Implementations: Istanbul Metropolitan Municipality Social Aid Unit", Local Policies, pp.53-84.

Türkoğlu, í. (2013). "Social Aid and Social Security in Turkey Within Social State Context", Journal of Academic Inquiries, 8(3), pp.275-305. 